This is an Open Access article distributed under the terms of the Creative Commons Attribution 4.0 International License which permits unrestricted non-commercial use, distribution, and reproduction in any medium, provided the original work is properly cited.

\title{
RHETORIC IN NURSING
}

Moh. Zainudin, M.Pd. ${ }^{1}$, Windu Santoso, M.Kep. ${ }^{2}$, Eka Nurjanah, M.Pd. ${ }^{3}$

Lecturer at Bina Sehat PPNI Institute Health of Science ${ }^{1,2}$

Lecturer University Pesantren Tinggi Darul Ulum Jombang ${ }^{3}$

Email: zainudin@stikes-ppni.ac.id,windu@stikes-ppni.ac.id, ekanurjanah@fai.unipdu.ac.id

\section{Dear Editor,}

There are several titles for rhetoric, such as the science of speech, and the art of effective language use (Sutrisno, 2014). The use of effective language is necessary in nursing science, as it will assist the patient in the healing process. This will not escape the theory of caring, as a central theory in nursing practice. (Muhlisin, 2004). It can be seen through caring behaviors such as: (1) introducing themselves and making relationship contracts, (2) calling clients by name, (3) using touch (healing), (4) always motivating clients, (5) (7) fulfilling the client's basic needs (willingly), (8) explaining the action to be taken, (9) the active listener, (10) being honest, ( 11) empathy, and (12) can control feelings (Afifah \& Kes, 1999).

Based on caring behavior, it is seen that the core of all such behavior is communication. Communication will work well when communication components are met, namely: (1) communicator (information giver), (2) communicant (recipient of information), (3) messages (ideas, facts, information etc.), (4) media (the channel used to convey the message), (5) the encoding activity (the formulation of messages by the communicator), and (6) the decoding activities (interpretation of messages by the communicant) (Lestari, 2010).

In this regard a nurse needs to understand the five laws of rhetoric, namely inventio, dispositio, elucotio, memoria, and pronuntiatio (Perkembangan, 2005). First Inventio. At this stage the speaker explores topics and researches the audience to find out the most appropriate method of persuasion. Speakers also formulate objectives and collect materials that fit the needs of audiences. Second Dispositio. At this stage the speaker organizes the message. Messages are divided into logically consecutive sections. The arrangement is usually an introduction, statement, argument, and epilogue. Third Elucotio. At this stage the speaker chooses the 
right diction to pack the message. This can be done by: using appropriate, correct, acceptable language, choosing clear and direct words, using beautiful, noble and living sentences, and customizing the language with messages, audiences, and speakers. fourth is Memoria. At this stage the speaker should remember what to say to the speaker. Fifth Pronuntiatio. At this stage the speaker delivered his oral message. Noteworthy is the sound and movement of limbs.

Furthermore, according to Aristotle, there are three methods of persuasion, namely ethos, pathos, and logos, in which ethos is the ability to show others that the speaker has a broad knowledge, a trusted personality, and an honorable status. while the pathos are speakers able to touch the hearts of the audience, both emotion, hope, hate, and affection of the listener. Finally, logos, the speakers present reasonable proof of the message (Kepemimpinan \& Dasar, 2007).

This letter informs that, if these three persuasive formulas are associated with caring, then the dominant one is leading to the fourth point in caring theory, which is always motivating the client. Motivation for the client is very important because motivation is the driving force of human behavior to achieve a certain goal that is the purpose to meet the psychic and physical needs (Psikologi, Pendidikan, \& Semarang, 2013). The client will be willing to listen if the nurse has extensive knowledge in the field of his or her knowledge. Clients can be happy if the nurse is able to process the mood of the client. Is empathy, sympathy, hope and so forth. The client will also decide to act if the evidence presented by the nurse related to the topic of the conversation makes sense.

\section{REFERENCES}

Afifah, E., \& Kes, M. (1999). Concept Caring, 1-3. Leadership, L. \& Basic, T. (2007). What is tho the rhetoric ... ??

Lestari, S. P. (2010). Therapeutic communication. Therapeutic Communication, 1-28.

Muhlisin, A. (2004). Caring Conceptual Model Model From Jean Watson In Nursing Care. Conceptual Caring Model Applications From Jean Watson, 147-150.

Development, S. D. A. N. (2005). History and Development of Rhetoric, 17 (2), 142-153.

Psychology, J., Pendidkan, F. I., \& Semarang, U. N. (2013). Therapeutic Communication Relations.

Sutrisno, I. (2014). Rhetorical Review for Knowledge Development and Speech Skills, 12 (April), 70-84. 